\title{
A plant-based extract mixture for controlling Spodoptera litura (Lepidoptera: Noctuidae)
}

\author{
Thitaree Yooboon ${ }^{1}$, Anchulee Pengsook ${ }^{2}$, Atcharee Ratwatthananon², Wanchai Pluempanupat ${ }^{2 *}$ \\ and Vasakorn Bullangpoti ${ }^{1^{*}}$ (D)
}

\begin{abstract}
Background: Spodoptera litura larvae are polyphagous insects that have become a significant pest in recent years. The spread of this pest has led to the continuous usage of insecticides on crops. Some plant extracts have been used as a mixture to control insect pests and improve productivity.

Methods: A plant-based mixture was mixed at a ratio of 1:1 v/v to demonstrate the effect on contact toxicity, feeding (no-choice test), and enzyme activities on S. litura. The active compounds of P. retrofractum and A. calamus were isolated by preparative thin-layer chromatography (PTLC).

Results: Our results showed that binary mixtures from $P$. retrofractum and $A$. calamus exhibit the highest contact toxicity and antifeedant activity at a 1:1 ratio of $\mathrm{LD}_{30}: \mathrm{LD}_{10}$ dose $(3.213 \mu \mathrm{g} / \mathrm{larva}$ P. retrofractum $+3.294 \mu \mathrm{g} /$ larva A. calamus). The main active ingredient from each crude extract was $(2 E, 4 E, 14 Z)-N$-isobutylicosa-2,4,14-trienamide from $P$. retrofractum, and beta-asarone and alpha-asarone from A. calamus. Additionally, A. calamus seems to be the synergistic compound. Some compound mixtures increased the glutathione-S-transferase activities in vivo; whereas, almost no significant differences in esterase activities were noted.

Conclusion: The results indicated that the ethanolic crude extracts of $P$. retrofractum and A. calamus mixtures could be used as the pesticidal compound and to develop a binary mixture formulation for controlling lepidopteran pests. However, the toxicity of this mixture to mammals needed to be explored before commercial development.
\end{abstract}

Keywords: Spodoptera litura, Plant extract mixture, Synergist, Detoxification enzymes, Antifeedant

\section{Introduction}

Spodoptera litura (Lepidoptera: Noctuidae) is a polyphagous insect pest that feeds on at least 87 plant species in over 40 plant families, including many vegetables, fruit, cotton, groundnut, chili, tobacco, castor, lady finger, cauliflower, and pulses, in many Asian countries, such as Thailand, China, Japan, India [1-3]. It has gradually become a significant insect pest in recent years [4]. The spread of this pest has led to the continuous usage of insecticides on crops. Pesticide residues impact the

\footnotetext{
*Correspondence: fsciwcp@ku.ac.th; fscivkb@ku.ac.th

${ }^{1}$ Animal Toxicology and Physiology Specialty Research Unit, Department of Zoology, Faculty of Science, Kasetsart University, Phahonyothin Road, Bangkok 10900, Thailand

${ }^{2}$ Department of Chemistry and Center of Excellence for Innovation in Chemistry, Faculty of Science, and Special Research Unit for Advanced Magnetic Resonance, Kasetsart University, Bangkok 10900, Thailand
}

environment and people's health [5]. These results of insecticide usage have encouraged scientists to seek less hazardous chemicals and identify an alternative method for integrated pest management (IPM).

Botanical extract products have become more prominent in assessments of current and future pest control alternatives. They are biodegradable and ecologically safe and an important component of IPM programs [6]. For instance, numerous studies have focused on neem (Azadirachta indica A. Juss), and a number of studies demonstrate efficacy against a variety of pests $[7,8]$. Its compound has numerous activities against insects, such as antifeedant, growth inhibition, growth regulation, reduced fecundity and sterility, and inhibition of protein synthesis, as well as toxic effects in a wide variety of insect taxa, including Lepidoptera [7, 8]. Plants comprise a source of novel chemical compounds that are used in 
medicine and other applications. Each plant contains many active compounds, such as terpenes, terpenoids alkaloids, steroids, phenols, and flavonoids [9], which are found in specific parts, i.e., leaves, flowers, stems, fruits, seeds, roots. Plant defense compounds typically result from a combination of these plant products and not as individual compounds.

A variety of documents suggest that complex mixtures would be more efficient, and synergistic effects have been reported [10, 11]. Singh et al. [12] demonstrated that thymol and $\alpha$-terpineol synergized the impacts of both linalool and 1,8-cineole, but linalool with 1,8-cineole exhibited only an additive effect against Chilo partellus. trans-Anethole acted synergistically with thymol, citronellal and $\alpha$-terpineol [13]. Consequently, the mixtures of plant compounds are also likely to be more durable against insects evolving resistance and developing behavioral desensitization.

This study was focused on the effect of six plant extracts, including Acorus calamus (Acorus calamus: Acorus calamus), Alpinia galanga (Zingiberaceae: Zingiberales), Curcuma longa (Zingiberaceae: Zingiberales), Piper nigrum (Piperaceae: Piperales), Piper retrofractum (Piperaceae: Piperales), and Sphagneticola trilobata (Asteraceae: Asterales), on S. litura control. These plant species are well known for their natural properties in the Thai traditional system of medicine or growth as a weed and have been reported to possess numerous types of biological activities.

Numerous anti-insect properties of the six plants involve toxic effects against many insects. Lee et al. [14] demonstrated the insecticidal effect of the methanol extract of C. longa rhizome on Plutella xylostella larvae. The hexane and ethanol extracts of rhizomes of $A$. galanga exhibit insecticidal activity against the fruit fly Bactrocera dorsalis when applied using a direct spray technique [15]. The essential rhizome oil of $A$. calamus showed a sterilizing effect against the eggs of Sitophilus granarius, Sitophilus oryzae, and Culiosobruchus chinensis [16] and larvicidal activity against Culex quinquefasciatus [17]. Upadhyay and Jaiswal found that $0.2 \mu \mathrm{l}$ of $P$. nigrum oil significantly repelled Tribolium castaneum [18]. The dichloromethane extract of P. nigrum has pesticidal activity against Callosobruchus maculates and Sitophilus zeamais [19]. In addition to P. nigrum, P. retrofractum, which is in the same genus, also showed larvicidal activity against mosquito larvae $C$. quinquefasciatus [20]. Moreover, S. trilobata crude extracts have a larvicidal effect on S. litura, S. exigua, and P. xylostella larvae after topical application [21].

However, there is no research on the extract efficiency of the binary mixture in S. litura. The literature suggests that complex mixtures would be more effective than pure or only one crude extract $[12,13]$. Thus, this research has the main goal of producing a plant-based mixture for control of S. litura with the possibility of increasing the control efficiency. Additionally, detoxification enzyme activities on treated $S$. litura were analyzed to search for the possibility of controlling this pest and examining the trends of resistance to this plant-based product in the future.

\section{Materials and methods}

\section{Insect rearing}

Spodoptera litura larvae used in this study were obtained from a laboratory colony maintained in the Animal Toxicology and Physiology Specialty Research Unit (ATPSRU), Department of Zoology, Faculty of Science, Kasetsart University. The culture was continuously maintained on an artificial diet (mixture of $240 \mathrm{~g}$ of green bean, $25 \mathrm{~g}$ of agar, $40 \mathrm{ml}$ of mixed vitamin solution, $5 \mathrm{~g}$ of ascorbic acid, $40 \mathrm{ml}$ of amoxicillin solution, $3 \mathrm{~g}$ of sorbic acid, $5 \mathrm{~g}$ of methylparaben, $20 \mathrm{~g}$ of yeast, $4 \mathrm{ml}$ of $40 \%$ formalin and $1.41 \mathrm{l}$ of water) in the insect-rearing room of the Department of Zoology, Faculty of Science, Kasetsart University, at $26{ }^{\circ} \mathrm{C}$ with $75 \% \mathrm{RH}$ and a $16: 8-\mathrm{h} \mathrm{L}: \mathrm{D}$ photoperiod. Second and third instar larvae were used randomly for the treatment. All experimental procedures in this research were performed with the approval of an appropriate animal Ethics Committee of Kasetsart University, Thailand, under the reference number OACKU01059.

\section{Plant materials and extraction methods}

The rhizomes of A. galanga, $C$. longa, and A. calamus; the leaves and stem of S. trilobata; and the fruits of P. nigrum and $P$. retrofractum were obtained from Banphoromyen, Amphawa, Samut Songkhram province, Thailand. Each plant was rinsed with water to remove debris and air dried under shade. Dried plants were chopped finely to a powder. One kilogram of each powder sample was soaked in ethanol for 14 days. Each crude extract was filtered using a vacuum pump, dried by a rotary evaporator to obtain the solidified crude extracts and stored at $4{ }^{\circ} \mathrm{C}$ in a refrigerator until further processing.

\section{Preliminary test of the contact toxicity bioassay for crude extract}

Contact toxicity bioassays were performed with second instar larvae of $S$. litura. Each ethanolic crude extract was evaluated individually to determine efficacy levels upon topical application to the thorax region with various concentrations of extracts $(2-140 \mu \mathrm{g} / \mathrm{larva})$ using acetone as a carrier. Each second instar larva received $2 \mu \mathrm{l}$ of extract per treatment for the thoracic region, and acetone alone served as the control. Thirty insects at each 
concentration were used with five biological replicates. After treatment, larvae were maintained in the insectrearing room and allowed to feed on an artificial diet. Mortality was recorded every day post-treatment. The median lethal dose $\left(\mathrm{LD}_{50}\right)$ and sublethal dose $\left(\mathrm{LD}_{10}\right.$ and $\mathrm{LD}_{30}$ ) at 24 and $48 \mathrm{~h}$ after exposure were calculated by Probit analysis using the Statplus program (version 2017, Analyst company, Canada).

Three extracts that showed the best control efficiency were chosen to make compound mixtures and subsequent analysis of the active ingredient compounds.

\section{Isolation method}

Major components of the fruits of $P$. retrofractum extract were isolated by preparative thin layer chromatography (PTLC) with $30 \%$ ethyl acetate (EtOAc) in hexane to yield a major compound identified as piperine (15.6\%), whereas $(2 E, 4 E, 14 Z)-N$-isobutylicosa-2,4,14-trienamide (6.2\%) was obtained by PTLC using $10 \%$ EtOAc in hexane followed by $15 \%$ EtOAc in hexane. The ${ }^{1} \mathrm{H}$ and ${ }^{13} \mathrm{C}$ NMR spectra were recorded on a Bruker $400 \mathrm{MHz}$ AVANCE III HD spectrometer operating at $400 \mathrm{MHz}$ $(1 \mathrm{H})$ and $100 \mathrm{MHz}(13 \mathrm{C})$. The high-resolution mass spectra (HRMS) were recorded on a MAXIS (Bruker).

\section{Piperine}

Pale yellow solid; ${ }^{1} \mathrm{H}$ NMR (400 $\mathrm{MHz}, \mathrm{CDCl}_{3}$ ): $\delta 7.39$ (ddd, $J=14.7,8.4,1.8 \mathrm{~Hz}, 1 \mathrm{H}), 6.96(\mathrm{~d}, J=1.6 \mathrm{~Hz}, 1 \mathrm{H}$ ), 6.87 (dd, $J=8.0,1.6 \mathrm{~Hz}, 1 \mathrm{H}), 6.78-6.70(\mathrm{~m}, 3 \mathrm{H}), 6.42$ $(\mathrm{d}, J=14.7 \mathrm{~Hz}, 1 \mathrm{H}), 5.94(\mathrm{~d}, J=4.7 \mathrm{~Hz}, 2 \mathrm{H}), 3.56$ (s, 4 $\mathrm{H}), 1.74-1.46(\mathrm{~m}, 6 \mathrm{H}) .{ }^{13} \mathrm{C}$ NMR $\left(100 \mathrm{MHz}, \mathrm{CDCl}_{3}\right): \delta$ $165.59,148.34,148.26,142.64,138.38,131.12,125.51$, $122.65,120.20,108.64,105.82,101.42,47.07,43.38$, 26.87, 25.80, 24.81. HRMS (ESI) Calcd for $\mathrm{C}_{17} \mathrm{H}_{19} \mathrm{NNaO}_{3}$ $308.1263\left([\mathrm{M}+\mathrm{Na}]^{+}\right)$, Found 308.1278.

\section{(2E,4E, 14Z)-N-isobutylicosa-2,4, 14-trienamide}

Pale yellow oil; ${ }^{1} \mathrm{H}$ NMR $\left(400 \mathrm{MHz}, \mathrm{CDCl}_{3}\right) \delta 7.18$ (dd, $J=15.0,9.9 \mathrm{~Hz}, 1 \mathrm{H}), 6.16-5.99(\mathrm{~m}, 2 \mathrm{H}), 5.77(\mathrm{~d}$, $J=15.1 \mathrm{~Hz}, 1 \mathrm{H}), 5.72(\mathrm{~s}, 1 \mathrm{H}), 5.36-5.31(\mathrm{~m}, 2 \mathrm{H}), 3.14(\mathrm{dd}$, $J=12.3,5.8 \mathrm{~Hz}, 2 \mathrm{H}), 2.12(\mathrm{dd}, J=13.7,7.1 \mathrm{~Hz}, 2 \mathrm{H}), 2.05-$ $1.97(\mathrm{~m}, 4 \mathrm{H}), 1.85-1.73(\mathrm{~m}, 1 \mathrm{H}), 1.62(\mathrm{dt}, J=15.2,7.8 \mathrm{~Hz}$, $1 \mathrm{H}), 1.43-1.37(\mathrm{~m}, 2 \mathrm{H}), 1.29$ (ddd, $J=19.8,9.3,4.0 \mathrm{~Hz}$, 16H), 0.93-0.84 (m, 9H). ${ }^{13} \mathrm{C}$ NMR (100 MHz, $\mathrm{CDCl}_{3}$ ) $\delta 166.72,143.43,141.55,129.98,128.32,121.76,47.10$, $32.08,31.89,29.90-29.19,28.93,28.72,27.30,27.02$, 22.45, 20.24, 14.11. HRMS (ESI) Calcd for $\mathrm{C}_{24} \mathrm{H}_{43} \mathrm{NNaO}$ $384.3242\left([\mathrm{M}+\mathrm{Na}]^{+}\right)$, Found 384.3235.

For the ethanolic extract of the rhizomes of $A$. calamus, the major spot on TLC was isolated by PTLC using $25 \%$ EtOAc in hexane to obtain fraction 1 (17.1\%). For structural analysis using ${ }^{1} \mathrm{H} \mathrm{NMR}$, this fraction was identified as a mixture of beta-asarone and alpha-asarone (ratio
4.38/1) and confirmed by authentic compounds purchased from Sigma-Aldrich.

\section{Asarone mixture}

Colorless oil; ${ }^{1} \mathrm{H}$ NMR (400 $\mathrm{MHz}, \mathrm{CDCl}_{3}$ ): beta-asarone: $\delta 6.84(\mathrm{~s}, 1 \mathrm{H}), 6.53,(\mathrm{~s}, 1 \mathrm{H}), 6.48(\mathrm{~m}, 1 \mathrm{H}), 5.77(\mathrm{dq}, 1 \mathrm{H}$, $J=11.5,7.0 \mathrm{~Hz}), 3.90(\mathrm{~s}, 3 \mathrm{H}), 3.84(\mathrm{~s}, 3 \mathrm{H}), 3.81(\mathrm{~s}, 3 \mathrm{H})$, $1.84(\mathrm{dd}, 3 \mathrm{H}, J=6.6,1.8 \mathrm{~Hz})$; alpha-asarone: $\delta 6.94(\mathrm{~s}$, $1 \mathrm{H}), 6.65(\mathrm{dq}, 1 \mathrm{H}, J=15.8,1.7 \mathrm{~Hz}), 6.49(\mathrm{~s}, 1 \mathrm{H}), 6.09(\mathrm{dq}$, $1 \mathrm{H}, J=16.0,6.6 \mathrm{~Hz}), 3.88(\mathrm{~s}, 3 \mathrm{H}), 3.85(\mathrm{~s}, 3 \mathrm{H}), 3.82(\mathrm{~s}$, $3 \mathrm{H}), 1.88(\mathrm{dd}, 3 \mathrm{H}, J=6.6,1.8 \mathrm{~Hz})$.

\section{Contact toxicity bioassay for pure compounds}

Similar to the crude extract, a contact toxicity bioassay was performed with second instar larvae of S. litura. Each purified compound was evaluated individually to determine their efficacy levels upon $2-\mu \mathrm{l}$ topical application to the thorax region with various concentrations $(2-100 \mu \mathrm{g} /$ larva) using acetone as a carrier at concentration. Thirty insects at each concentration were used with five biological replicates. After treatment, larvae were maintained in the insect-rearing room and allowed to feed on an artificial diet. Mortality was recorded at $24 \mathrm{~h}$ post-treatment. The median lethal dose $\left(\mathrm{LD}_{50}\right)$ at $24 \mathrm{~h}$ after exposure was calculated by Probit analysis using the Statplus program (version 2017, Analyst Company, Canada).

\section{Mixture concentration preparation methods}

The compound mixtures of plants were prepared and modified from Hummelbrunner and Isman [13] by choosing the dose at $\mathrm{LD}_{30}$ or $\mathrm{LD}_{10}$ values of $S$. litura after contact toxicity analysis.

The $\mathrm{LD}_{10}$ and $\mathrm{LD}_{30}$ values of two extracts that showed the best control efficiency were chosen to make compound mixtures. Each crude extract was prepared to a specific concentration by dissolving in acetone. Then, $1 \mathrm{ml}$ of each crude extract was mixed at a ratio of $1: 1 \mathrm{v} / \mathrm{v}$. The mixture was then used to analyze the contact toxicity and antifeedant efficiency.

\section{Contact toxicity assay for compound mixtures}

As described above, each mixture was treated with S. litura larvae by topical application. A minimum of 30 insects/combination was used for each experiment, and five replicates were performed. After $24 \mathrm{~h}$, mortality was recorded. Actual mortalities were compared with expected mortalities based on the formula described as follows:

$$
E=O_{\mathrm{a}}+O_{\mathrm{b}}\left(1-O_{\mathrm{a}}\right),
$$

where $E$ is the expected mortality and $O_{\mathrm{a}}$ and $O_{\mathrm{b}}$ are the observed mortalities of extracts at the given concentration. The effects of mixtures were designated 
antagonistic, additive, or synergistic by analysis using $x^{2}$ comparisons from the following formula:

$$
\chi^{2}=\left(\left(O_{\mathrm{m}}-E\right)^{2} / E\right),
$$

where $O_{\mathrm{m}}$ is the observed mortality from the binary mixture and $\mathrm{E}$ is the expected mortality. In addition, $\chi^{2}$ with $d f=1$ and $\alpha=0.05$ is 3.84. A pair with $\chi^{2}$ values $>3.84$ and having higher than expected mortality was considered to be synergistic (negative $=$ antagonist effect), with $\chi^{2}$ values $<3.84$ representing additive effects. An observed mortality less than expected suggested an antagonistic effect of the mixtures. The mixtures that showed a synergistic effect were used for antifeedant and enzyme assays.

\section{Antifeedant bioassay for compound mixtures}

The no-choice bioassay investigated the antifeedant effect. Each binary mixture was applied to kale leaf discs $\left(4 \mathrm{~cm}^{2}\right)$ using a micropipette with $2 \mu \mathrm{l}$ on each side [22] and allowed to air dry at room temperature before releasing early third instar larva onto the discs. Each larva that was starved for $4 \mathrm{~h}$ was placed in a Petri dish with one treated leaf disc and allowed to feed. Each treatment used 30 larvae with three replicates. The uneaten area of the leaf disc was measured using a digitizing leaf area meter after $3 \mathrm{~h}$ of feeding. The percent feeding inhibition was calculated by using the formula from [23], $(C-T) /(C+T) \times 100$, where $C$ is the consumption of the control leaf and $T$ is the treated leaf cut.

\section{Enzyme assays}

\section{Enzyme extraction method}

Enzyme assays were performed in an in vivo experiment. The combined mixtures were tested with the second instar of S. litura larvae to optimize its effect on detoxification enzyme activities. Acetone was used as a control group. After $24 \mathrm{~h}$, the surviving larvae were used for enzyme extraction to determine the activities of esterase and glutathione-S-transferase. The extraction method was modified from Feyereisen [24], and surviving larvae were placed in a microtube and kept on ice. Then, larvae were ground with homogenized buffer $(0.1 \mathrm{M}$ potassium phosphate buffer mixed with $1 \mathrm{mM}$ EDTA at $\mathrm{pH}$ 7.2). Homogenates were centrifuged at $4{ }^{\circ} \mathrm{C}$ and $12,000 \mathrm{rpm}$ for $15 \mathrm{~min}$. The supernatants were transferred to new tubes and kept on ice immediately to study the different enzyme activities.

\section{Esterase activity (EST)}

The esterase activity was determined by the method of Bullangpoti et al. [25] with modifications. Enzyme solution $(40 \mu \mathrm{l})$ was mixed with $p$-nitrophenylacetate (pNPA) (10 $\mathrm{mM}$ in DMSO) and potassium phosphate buffer (50 mM, pH 7.4). Enzyme activity was measured at $410 \mathrm{~nm}$ and $37^{\circ} \mathrm{C}$ for $90 \mathrm{~s}$ in a 96-well plate in a microplate reader using the kinetic mode. EST activity was determined using the extinction coefficient of 176.4705 for pNPA.

\section{Glutathione-S-transferase activity (GST)}

The glutathione- $S$-transferase method was modified from Oppenoorth et al. [26]. The mixtures containing $50 \mathrm{mM}$ phosphate buffer $(\mathrm{pH} 7.2)$ were mixed with glutathione solution, supernatant, and 1-chloro-2,4'-dinitrobenzene (CDNB). Then, the activity of the mixtures was measured at a wavelength of $340 \mathrm{~nm}$ using a microplate reader. The GST activity was determined from the extinction coefficient of 0.000137 for CDNB. Three biological replicates per treatment were estimated.

\section{Results}

\section{Extract yields}

Alpinia galanga, $P$. nigrum and $P$. retrofractum extracts obtained were dark brown gum, whereas S. trilobata and C. longa extracts were dark green gum and orange gum, respectively. A. calamus extract was a yellow viscous semisolid. The percent yields were calculated by comparing the mass of crude extracts to the amount of fresh materials. The highest yield was obtained from ethanolic crude extraction from C. longa (Table 1).

\section{Preliminary toxicity results of crude extracts}

To determine the most effective extracts in this study, six ethanolic extracts were applied topically to second instar S. litura to assess toxicity. The median lethal dose values of each ethanolic extract are shown in Table 2. Among all extracts, $P$. retrofractum was the most effective extract against $S$. litura, followed by $A$. calamus and P. nigrum; whereas, A. galangal, S. trilobata, and C. longa were less efficient (Table 2). $A$. calamus and $P$. retrofractum were chosen for binary compound mixtures using $\mathrm{LD}_{10}$ and $\mathrm{LD}_{30}$ values. The $\mathrm{LD}_{10}$ and $\mathrm{LD}_{30}$ values were 3.294 and $6.735 \mu \mathrm{g} / \mathrm{larva}$, respectively, for $A$. calamus and 1.448 and $3.213 \mu \mathrm{g} /$ larva, respectively, for $P$. retrofractum.

\section{Preliminary toxicity results of purified compounds}

Base on the high toxicity of crude extracts, A. calamus, and $P$. retrofractum were chosen for analysis of the main effective chemical constituents for quality assessment of the mixture product for potential future development for commercial use. The major components from 
Table 1 The amount of ethanolic crude extracts derived from six plant species

\begin{tabular}{llll}
\hline Crude extracts & Weight $\mathbf{( g )}$ & $\begin{array}{l}\text { Percentage yield of plant extracts }(\% \text { w/w) } \\
\text { (\%) }\end{array}$ & Appearance \\
\hline C. longa & 90.76 & 9.076 & Orange gum \\
A. galanga & 29.39 & 2.939 & Dark brown gum \\
S. trilobata & 28.20 & 2.820 & Dark green gum \\
P. nigrum & 31.03 & 3.103 & Dark brown gum \\
A. calamus & 23.07 & 2.307 & Yellow viscous semisolid \\
P. retrofractum & 12.02 & 2.405 & Dark brown gum \\
\hline
\end{tabular}

Table 2 Toxicity of different ethanolic plant extracts ( $\mu \mathrm{g} / \mathrm{larva}$ ) against second instars of S. litura

\begin{tabular}{|c|c|c|c|c|c|c|}
\hline \multirow{2}{*}{$\begin{array}{l}\text { Compounds } \\
\text { Dose }\end{array}$} & \multicolumn{2}{|l|}{ C. longa } & \multicolumn{2}{|l|}{ S. trilobata } & \multicolumn{2}{|l|}{ A. galanga } \\
\hline & $24 \mathrm{~h}$ & $48 \mathrm{~h}$ & $24 \mathrm{~h}$ & $48 h$ & $24 \mathrm{~h}$ & $48 \mathrm{~h}$ \\
\hline $\mathrm{LD}_{50}$ & 108.894 & 106.171 & 41.993 & 41.141 & 30.5 & 29.703 \\
\hline $\mathrm{LD}_{50} \mathrm{SE}$ & 12.104 & 11.77 & 3.466 & 3.39 & 3.472 & 3.366 \\
\hline Chi square & 31.26 & 20.83 & 8.83 & 7.95 & 3.72 & 3.74 \\
\hline $\mathrm{LD}_{50} \mathrm{LCL}$ & 90.81 & 88.492 & 35.64 & 34.913 & 24.27 & 23.643 \\
\hline $\mathrm{LD}_{50} \cup C L$ & 240.274 & 136.542 & 49.239 & 48.207 & 37.882 & 36.831 \\
\hline Slope \pm SE & $2.30 \pm 0.31$ & $2.25 \pm 0.29$ & $2.28 \pm 0.23$ & $2.29 \pm 0.23$ & $1.64 \pm 0.17$ & $1.65 \pm 0.17$ \\
\hline \multirow{2}{*}{$\begin{array}{l}\text { Compounds } \\
\text { Dose }\end{array}$} & \multicolumn{2}{|l|}{ P. nigrum } & \multicolumn{2}{|l|}{ A. calamus } & \multicolumn{2}{|c|}{ P. retrofractum } \\
\hline & $24 \mathrm{~h}$ & $48 h$ & $24 \mathrm{~h}$ & $48 \mathrm{~h}$ & $24 \mathrm{~h}$ & $48 \mathrm{~h}$ \\
\hline$L_{50}$ & 27.91 & 25.805 & 11.044 & 9.78 & 5.575 & 5.522 \\
\hline $\mathrm{LD}_{50} \mathrm{SE}$ & 3.227 & 2.891 & 0.87 & 0.804 & 0.522 & 0.507 \\
\hline Chi square & 3.04 & 2.84 & 4.62 & 5.75 & 0.53 & 0.45 \\
\hline $\mathrm{LD}_{50} \mathrm{LCL}$ & 22.37 & 20.752 & 9.474 & 8.319 & 4.597 & 4.569 \\
\hline $\mathrm{LD}_{50} \mathrm{UCL}$ & 35.042 & 32.169 & 12.9 & 11.479 & 6.631 & 6.546 \\
\hline Slope \pm SE & $1.41 \pm 0.13$ & $1.44 \pm 0.13$ & $2.44 \pm 0.22$ & $2.30 \pm 0.21$ & $2.19 \pm 0.27$ & $2.24 \pm 0.27$ \\
\hline
\end{tabular}

$L D_{50}$ lethal dosage that kills $50 \%$ of the exposed larvae, expressed in $\mu \mathrm{g} /$ larvae; $S E$ standard error; $L C L$ lower confidence limit; UCL upper confidence limit

P. retrofractum were piperine (15.6\%) and $(2 E, 4 E, 14 Z)$ $N$-isobutylicosa-2,4,14-trienamide (6.2\%); whereas, the major component from A. calamus was asarone $(17.1 \%$, ratio of beta/alpha $=4.38 / 1)$ (Table 2). The structures of isolated compounds are presented in Fig. 1. From Table 3, the toxicity results of all isolated compounds showed that $(2 E, 4 E, 14 E)-N$-isobutylicosa-2,4,14-trienamide was the active compound of $P$. retrofractum $\left(\mathrm{LD}_{50}=1.66 \mu \mathrm{g} /\right.$ larva) and that alpha-asarone was the active compound of $A$. calamus $\left(\mathrm{LD}_{50}=2.22 \mu \mathrm{g} /\right.$ larva $)$.

\section{Contact toxicity of compound mixtures}

The 2 best crude extracts at $\mathrm{LD}_{10}$ and $\mathrm{LD}_{30}$ doses were mixed, resulting in 4 paired combinations to investigate the synergistic effect of binary mixtures. Each mixture was used to topically treat S. litura, and mortality was observed at $24 \mathrm{~h}$. This binary bioassay revealed that the combination of $P$. retrofractum and A. calamus exhibited synergistic toxicity against $S$. litura (Table 4 ).

\section{Antifeedant effects of binary mixtures}

The antifeedant activity of the binary mixtures was performed using a no-choice assay. The results showed that the percentage of feeding inhibition of binary mixtures was $15.12-82.43 \%$ after $3 \mathrm{~h}$ of feeding. Among these combinations, the mixture of $3.213 \mu \mathrm{g} /$ larvae $P$. retrofractum with $3.294 \mu \mathrm{g} /$ larvae $A$. calamus was very efficient with $82.43 \%$ feeding inhibition compared with others (Table 5).

\section{Effect of binary mixtures on enzyme activities}

Based on antifeedant activity, we hypothesized that this binary mixture affected detoxification enzyme activity. The results revealed that GST activity as assessed by in vivo assays was induced after treatment with mixtures (Table 6). Moreover, significant increases between the control and treated groups $(p<0.05$, $d f=7)$ in vivo were noted for GST $(1.488 \mu \mathrm{g} /$ larvae $P$. 


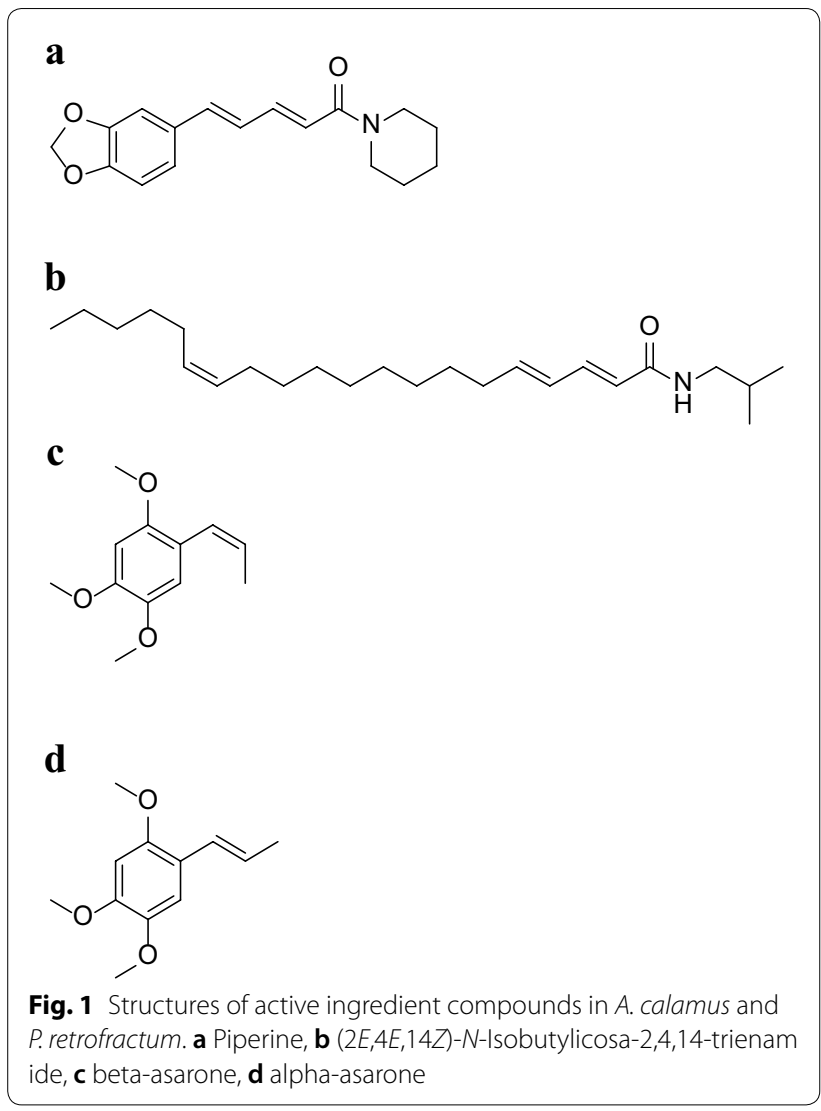

retrofractum $+6.735 \mu \mathrm{g} /$ larvae $A$. calamus and $1.488 \mu \mathrm{g} /$ larvae $P$. retrofractum $+3.294 \mu \mathrm{g} /$ larvae $A$. calamus) (Table 6).

\section{Discussion}

Plant extracts as sources of bioactive and therapeutic purposes have been used for thousands of years [27]. Plant extracts and their derivatives have been evaluated for different pest control properties, e.g., their toxicity, repellent, antifeedant, fumigation, and effect on oviposition activities [28].

In this study, six plant extract compounds were extracted by ethanol, and the goal is that the farmer can use this knowledge to develop insecticides to control S. litura by themselves, potentially reducing the cost for pest control. All crude extracts evaluated via topical application against second instar S. litura larvae revealed that the ethanolic extract of $P$. retrofractum had the highest control efficiency, followed by $A$. calamus (Table 2). $P$. retrofractum and $A$. calamus are used as alternative medicines and supplements in primary health care worldwide $[29,30]$. They are less toxic to nontarget organisms and mammals. A previous study from Wiwattanawanichakun et al. showed that $P$. retrofractum was moderately toxic for guppy fish compared with the known data available for synthetic pesticides [31]. Moreover, the $\mathrm{LD}_{50}$ values for oral doses of $A$. calamus extracts were greater than $5000 \mathrm{mg} / \mathrm{kg}$ body weight in Wistar rats [32] and $5070.59 \mathrm{mg} / \mathrm{kg}$ in mice [33].

Among the six plant extracts, $P$. retrofractum had the most potent extract with an $\mathrm{LD}_{50}$ value of $5.575 \mu \mathrm{g} / \mathrm{larva}$. Similar results were reported by Chansang et al. [20] Among aqueous extracts of nine medicinal plants, $P$. retrofractum showed the highest level of activity against $C x$. quinquefasciatus and Aedes aegypti (L.) larvae with $\mathrm{LD}_{50}$

Table 3 Toxicity of some active compounds ( $\mu \mathrm{g} / \mathrm{larva}$ ) against second instars of S. litura at $24 \mathrm{~h}$

\begin{tabular}{|c|c|c|c|c|c|c|}
\hline & Plant source & $\mathrm{LD}_{50}$ & $\mathrm{LD}_{50} \mathrm{LCL}$ & $\mathrm{LD}_{50} \mathrm{UCL}$ & Slope \pm SE & Chi square \\
\hline Beta-asarone & A. calamus & 6.24 & 4.62 & 8.66 & $1.44 \pm 0.16$ & 5.67 \\
\hline Alpha-asarone & A. calamus & 2.22 & 1.74 & 2.61 & $2.94 \pm 0.42$ & 0.11 \\
\hline $\begin{array}{l}(2 E, 4 E, 14 Z)-N \text {-isobutyli- } \\
\text { cosa-2,4,14-trienamide }\end{array}$ & P. retrofractum & 1.66 & 1.34 & 1.95 & $2.19 \pm 0.33$ & 0.02 \\
\hline Piperine & P. retrofractum & 81.56 & 36.71 & 181.27 & $2.10 \pm 0.66$ & 28.86 \\
\hline
\end{tabular}

$L D_{50}$ lethal dosage that kills $50 \%$ of the exposed larvae, expressed in $\mu \mathrm{g} /$ larvae; $S E$ standard error; $L C L$ lower confidence limit; $U C L$ upper confidence limit

Table 4 Relative toxicity of binary mixtures against second instars of S. litura and measures of interactions

\begin{tabular}{|c|c|c|c|c|c|c|c|}
\hline \multirow[t]{2}{*}{ Crude A } & \multirow[t]{2}{*}{ Crude B } & \multicolumn{2}{|c|}{ Compound alone } & \multicolumn{2}{|c|}{ Binary Mixtures } & \multirow[t]{2}{*}{$x^{2}$} & \multirow[t]{2}{*}{ Effect } \\
\hline & & Observed A & Observed B & Expected & Observed & & \\
\hline 1.448 g/larva P. retrofractum & 3.294 ug/larva A. calamus & 0.10 & 0.07 & 0.16 & 0.27 & 7.06 & Synergistic \\
\hline $1.448 \mu \mathrm{g} /$ larva P. retrofractum & $6.735 \mu \mathrm{g} /$ larva A. calamus & 0.10 & 0.17 & 0.25 & 0.37 & 5.41 & Synergistic \\
\hline $3.213 \mu \mathrm{g} /$ larva P. retrofractum & 3.294 ug/larva A. calamus & 0.23 & 0.07 & 028 & 0.47 & 12.16 & Synergistic \\
\hline $3.213 \mu \mathrm{g} /$ larva P. retrofractum & $6.735 \mu \mathrm{g} /$ larva A. calamus & 0.23 & 0.17 & 0.36 & 0.50 & 5.58 & Synergistic \\
\hline
\end{tabular}


Table 5 The antifeedant activity induced by binary mixtures $(1: 1, v / v)$ against third instar S. litura larvae

\begin{tabular}{|c|c|c|}
\hline Plant extract & Ratio & Antifeeding percentage \\
\hline $1.448 \mu \mathrm{g} /$ larva P. retrofractum +3.294 $\mu \mathrm{g} /$ larva A. calamus & $\mathrm{LD}_{10}: \mathrm{LD}_{10}$ & $15.12 \pm 0.026$ \\
\hline $1.448 \mu \mathrm{g} /$ larva P. retrofractum $+6.735 \mu \mathrm{g} /$ larva A. calamus & $\mathrm{LD}_{10}: \mathrm{LD}_{30}$ & $42.69 \pm 0.033$ \\
\hline $3.213 \mu \mathrm{g} / \mathrm{larva}$ P. retrofractum + $3.294 \mu \mathrm{g} / \mathrm{larva}$ A. calamus & $\mathrm{LD}_{30}: \mathrm{LD}_{10}$ & $82.43 \pm 0.033$ \\
\hline $3.213 \mu \mathrm{g} /$ larva P. retrofractum $+6.735 \mu \mathrm{g} /$ larva A. calamus & $\mathrm{LD}_{30}: \mathrm{LD}_{30}$ & $63.22 \pm 0.023$ \\
\hline
\end{tabular}

Table 6 Effect of plant-based binary mixtures on detoxification enzyme activities of second instar S. litura larvae

\begin{tabular}{lrr}
\hline Mixture & Esterase ${ }^{\mathbf{a}}$ & $\begin{array}{c}\text { Glutathione- } \\
\text { S-transferase }\end{array}$ \\
\hline Control & & $1.61 \pm 0.07 \mathrm{a}$ \\
$1.448 \mu \mathrm{g} /$ larva P. retrofractum & $0.64 \pm 0.03 \mathrm{a}$ & $2.27 \pm 0.13 \mathrm{a}$ \\
$3.213 \mu \mathrm{g} /$ larva P. retrofractum & $0.68 \pm 0.06 \mathrm{a}$ & $1.64 \pm 0.02 \mathrm{a}$ \\
$3.294 \mu \mathrm{g} /$ larva A. calamus & $0.69 \pm 0.03 \mathrm{a}$ & $2.05 \pm 0.03 \mathrm{a}$ \\
$6.735 \mu \mathrm{g} /$ larva A. calamus & $0.73 \pm 0.08 \mathrm{a}$ & $1.674 \pm 0.02 \mathrm{a}$ \\
$1.448 \mu \mathrm{g} /$ larva P. retrofractum $+3.294 \mu \mathrm{g} /$ larva A. calamus & $0.72 \pm 0.03 \mathrm{a}$ & $1.84 \pm 0.02 \mathrm{~b}$ \\
$1.448 \mu \mathrm{g} /$ larva P. retrofractum $+6.735 \mu \mathrm{g} /$ larva A. calamus & $0.78 \pm 0.04 \mathrm{a}$ & $1.9 \pm 0.07 \mathrm{~b}$ \\
$3.213 \mu \mathrm{g} /$ larva P. retrofractum $+3.294 \mu \mathrm{g} /$ larva A. calamus & $0.76 \pm 0.07 \mathrm{a}$ & $1.79 \pm 0.04 \mathrm{~b}$ \\
$3.213 \mu \mathrm{g} /$ /arva P. retrofractum $+6.735 \mu \mathrm{g} /$ larva A. calamus & $0.80+0.02 \mathrm{a}$ & $1.7+0.06 \mathrm{~b}$ \\
\hline
\end{tabular}

Means within a column followed by the same letter are not significantly different (ANOVA)

a Carboxylesterase activity $\pm \mathrm{SE}$ (nM $p$-nitrophenol/min/mg protein)

b Glutathione-S-transferase activity \pm SE (CDNB conjugated product/mg protein/min)

values of 135 and $79 \mu \mathrm{g} / \mathrm{g}$, respectively. P. retrofractum exhibits insecticidal activity against many insect pests. It caused $100 \%$ mortality at a concentration of $0.5 \%$ against second instar Crocidolomia pavonana larvae [34]. This extract also exhibited a high knockdown effect on several test insects, including P. xylostella, C. pavonana, $C x$. quinquefasciatus, Ae. aegypti, and Coptotermes gestroi $[20,35]$.

Another Piperaceae plant in this research is $P$. nigrum, which is also among the top three for $S$. litura control. Kumar et al. [36] revealed that the ethanolic extracts of black and white $P$. nigrum were $30-40 \%$ less toxic than the extracts of Piper longum against $A$. aegypti larvae. Additionally, a hexane extract showed a toxic effect against second instar larvae of S. litura with an $\mathrm{LD}_{50}$ of $1824 \mu \mathrm{g} / \mathrm{g}$ insect [37].

Some reports described that the active compound extracted from the fruit part of $P$. retrofractum and $P$. nigrum is piperine $[38,39]$. This compound also showed insecticidal activity against larvae of plant insects and antimicrobial activity [38]. However, in our results, piperine does not provide efficient control of $S$. litura. Our study assessed another new active ingredient from this piperaceae plant crude extract called $(2 E, 4 E, 14 Z)-N$-isobutylicosa-2,4,14-trienamide.
The other crude extract that showed the highest $S$. litura control in our results is A. calamus. Many papers have been published on the biological activities of $A$. calamus. A total of $0.4 \%$ of ethanolic extracts yielded $63.3 \%$ mortality against third instar larvae of $P$. xylostella based on the leaf-dipping method [40]. Phongpaichit et al. [41] revealed that the crude methanol extract exhibited high antimicrobial activity on various microorganisms and fungi. The larvicidal activity of $A$. calamus is due to the presence of the primary chemical compound beta-asarone [17].

Schmidt and Streloke [42] investigated the chemical composition of $A$. calamus rhizome using beta-asarone as the major compound for control Prostephanus truncatus (Horn). Other chemicals investigated in A. calamus include ethyl isoeugenol, 3.9-decadien-ol-1,3-methyl6-(1-methylethenyl), 4-pentyl-1-(4propylcyclohexyl)1cy clohexene, and alpha-asarone, which also has toxicity to insects, such as S. litura and Liposcelis bostrychophila, and other bioactivities [43-45].

Furthermore, synergistic effects of complex mixtures are thought to be important in plant defenses against herbivory. Plants usually present defenses based on a group of compounds and not individual compounds [13]. Although the highest mortality was noted with the $P$. retrofractum extract compared with other extracts at the 
same dose in our study, the combination of each extract in a binary assay produced stronger toxicity.

In this study, $P$. retrofractum synergized the toxicity of $A$. calamus at all doses. Among all combinations, the mixture of $P$. retrofractum $+A$. calamus $\left(\mathrm{LD}_{30}: \mathrm{LD}_{10}\right)$ could be the chosen mixture for controlling this insect. Both combinations showed a synergistic effect and also exhibited higher antifeedant activity at $82.43 \%$ compared with others (Tables 4, 5).

Dadang et al. [46] reported the robust efficacy of a mixture of $P$. retrofractum with Annona squamosa and Aglaia odorata, which produced $100 \%$ and $94 \%$ mortality, respectively, in Crocidolomia pavonana after a $48-\mathrm{h}$ treatment with a $0.05 \%$ extract mixture. The extract mixture of $A$. odorata and $A$. squamosa yielded a synergistic combination with multiple actions, such as feeding inhibition and insecticidal activity [46].

Insects have well-developed defense mechanisms against insecticides and natural pathogens that involve various enzyme systems. It is well known that herbivorous insects use detoxification enzymes, including EST, GST, and cytochrome P450 monooxygenases, to metabolize toxic chemicals and secondary plant metabolites [47]. However, these enzymes are also induced by xenobiotics as one of the mechanisms responsible for the development of resistance in insects [48]. The enzyme activities from in vivo treatment are presented in Table 5. GST activities in treated insects that survived after $24 \mathrm{~h}$ of exposure revealed a significant increase in GST in the $P$. retrofractum $+A$. calamus mixture at all combinations compared with the control group (Table 6). Conversely, EST activity showed no significant difference between groups $(p \geq 0.05, d f=7)$ (Table 6). Kaur et al. [49] reported that the induction of detoxification enzyme activities depended on both the duration of treatment and concentrations [50]. Specifically, a prolonged treatment and high dose showed a higher increase in enzyme activity. Therefore, the ratio and concentration of the mixed compounds are essential given that a suitable concentration could possibly affect detoxification enzymes.

An induction of detoxification enzyme activity has been reported by Zhou et al. [51], demonstrating that extracts from Illicium verum fruit induced EST activity in Myzus persicae and also increased EST activity in the gypsy moth Lymantria dispar after feeding on a diet of aspen leaves supplemented with phenolic glycosides [52]. A similar result was found in S. litura after they fed on Melia toosendan extract, demonstrating that midgut esterase activities were significantly increased after 24 and $48 \mathrm{~h}$ of feeding and decreased after $72 \mathrm{~h} \mathrm{[53].}$

\section{Conclusion}

The results demonstrated that ethanolic crude extracts of A. calamus L., A. galangal, C. longa L., P. nigrum, P. retrofractum, and $S$. trilobata caused toxicity in S. litura. Additionally, binary mixtures of $P$. retrofractum and $A$. calamus showed synergistic effects, suggesting that these mixtures could serve as an acute toxicant or antifeedant. In particular, the mixture of $P$. retrofractum + A c calamus $\left(\mathrm{LD}_{30}: \mathrm{LD}_{10}\right)$ at this combination exhibited the highest antifeedant activity at $82.43 \%$, showing synergistic contact toxicity effects and no significant differences in both EST and GST activities compared with controls. Therefore, the combination of these two compounds may constitute a useful alternative approach for the development of a binary mixture formulation to control lepidopteran pests for use in an IPM system.

\section{Abbreviations}

PTLC: preparative thin layer chromatography; IPM: integrated pest management; EtOAc: ethyl acetate; GST: glutathione-S-transferase; EST: esterase; pNPA: p-nitrophenylacetate; CDNB: 1-chloro-2,4'-dinitrobenzene; ANOVA: analysis of variance.

\section{Authors' contributions}

VB and WP designed the experiment. TY, AP and AR performed the experiments. VB and WP wrote and reviewed the paper. VB and WP checked all the details. All authors read and approved the final manuscript.

\section{Acknowledgements \\ The authors are grateful and would like to thank the Science Achievement Scholarship of Thailand (SAST) and the funding from the Department of Zoology, Faculty of Science, Kasetsart University. VB mainly thanks the research funding support from ARDA, Thailand, and RSA58 from the Thailand Research Funding. TY would like to thank Mr. Anusorn Hansit for his encouragement and the members of ATPSRU for their cooperation in insect culture and help- ful comments on the manuscript. W. P. is grateful to the Center of Excellence for Innovation in Chemistry (PERCH-CIC), Office of the Higher Education Com- mission, Ministry of Education, for financial support.}

\section{Competing interests}

The authors declare that they have no competing interests.

Availability of data and materials

All data are presented in Tables 1, 2, 3, 4, 5, 6 .

\section{Consent for publication}

This research has been confirmed for publication in the journal.

\section{Ethics approval and consent to participate}

All experimental procedures in this research were performed with the approval of an appropriate animal Ethics Committee of Kasetsart University, Thailand, under reference number OACKU01059.

\section{Funding}

This research was funded by the Department of Zoology, Faculty of Science, Kasetsart University, the Agricultural Research Development Agency (ARDA) and the RSA58 funding from Thailand Research Funding, Thailand, and Science Achievement Scholarship of Thailand, Office of the Higher Education Commission.

\section{Publisher's Note}

Springer Nature remains neutral with regard to jurisdictional claims in published maps and institutional affiliations. 
Received: 13 December 2018 Accepted: 30 January 2019

Published online: 14 March 2019

\section{References}

1. Noma T, Garcia MC, Brewer M, Landis J, Gooch A. Citrus long-horned beetle Anoplophora chinensi. Michigan State University IPM program, Michigan State University's invasive species factsheets; 2010. p. 2.

2. Datta R, Kaur A, Saraf I, Singh IP, Kaur S. Effect of crude extracts and purified compounds of Alpinia galanga on nutritional physiology of a polyphagous lepidopteran pest, Spodoptera litura (Fabricius). Ecotoxicol Environ Saf. 2019:168:324-9.

3. Dinesh-Kumar A, Srimaan E, Chellappandian M, Vasantha-Srinivasan P, Karthi S, Thanigaivel A, et al. Target and non-target response of Swietenia Mahagoni Jacq. Chemical constituents against tobacco cutworm Spodoptera litura Fab. and earthworm, Eudrilus eugeniae Kinb. Chemosphere. 2018;199:35-43.

4. Gao C, Bei Y, Chen T, Gu X. On factors causing outbreak of Spodoptera litura (Fabricius). Acta Agric Zhejiangensis. 2004;16:332-5.

5. Aktar MW, Sengupta D, Chowdhury A. Impact of pesticides use in agriculture: their benefits and hazards. J Agrometeorol. 2009;2:1-12.

6. Kedia A, Prakash B, Mishra PK, Singh P, Dubey NK. Botanicals as eco friendly biorational alternatives of synthetic pesticides against $\mathrm{Cal}$ losobruchus spp. (Coleoptera: Bruchidae) —a review. J Food Sci Technol. 2015;52:1239-57.

7. The Schmutterer H, Foundation Neem. Neem tree. 2nd ed. India: Mumbai; 2002.

8. Koul O, Wahab S. Neem: today and in the new millennium. Dordrecht: Kluwer Academic Publishers; 2004

9. Senthil-Nathan S. Physiological and biochemical effect of neem and other Meliaceae plants secondary metabolites against lepidopteran insects. Front Physiol. 2013;4:1-17.

10. Anaya-Eugenio GD, Rivero-Cruz I, Bye R, Linares E, Mata R. Antinociceptive activity of the essential oil from Artemisia ludoviciana. J Ethnopharmacol. 2016;179:403-11.

11. Rizvi SAH, Ling S, Tian F, Xie F, Zeng X. Toxicity and enzyme inhibition activities of the essential oil and dominant constituents derived from Artemisia absinthium L. against adult Asian citrus psyllid Diaphorina citri Kuwayama (Hemiptera: Psyllidae). Ind Crops Prod. 2018;121:468-75.

12. Singh R, Koul O, Rup PJ, Jindal J. Toxicity of some essential oil constituents and their binary mixtures against Chilo partellus (Lepidoptera: Pyralidae). Int J Trop Insect Sci. 2009;29:93-101.

13. Hummelbrunner LA, Isman MB. Acute, sublethal, antifeedant, and synergistic effects of monoterpenoid essential oil compounds on the tobacco cutworm, Spodoptera litura (Lep., Noctuidae). J Agric Food Chem. 2001;49:715-20.

14. Lee HS, Shin WK, Song C, Cho KY, Ahn YJ. Insecticidal activities of arTurmerone identified in Curcuma longa rhizome against Nilaparvata lugens (Homoptera: Delphacidae) and Plutella xylostella (Lepidoptera: Yponomeutidae). J Asia Pac Entomol. 2001:4:181-5.

15. Sukhirun N, Pluempanupat W, Bullangpoti $\bigvee$, Koul O. Bioefficacy of Alpinia galanga (Zingiberaceae) rhizome extracts, (E)-p-acetoxycinnamyl alcohol, and (E) -p-coumaryl alcohol ethyl ether against Bactrocera dorsalis (Diptera: Tephritidae) and the impact on detoxification enzyme activities. J Econ Entomol. 2011;104:1534-40.

16. Risha EM, Elnahal AKM, Schmidt GH. Toxicity of vapors of Acorus calamus L Oil to the immature stages of some stored product Coleoptera. J Stored Prod Res. 1990:26:133-7.

17. Senthilkumar A, Venkatesalu V. Larvicidal potential of Acorus calamus L. essential oil against filarial vector mosquito Culex quinquefasciatus (Diptera : Culicidae). Asian Pac J Trop Dis. 2012;2:324-6.

18. Upadhyay R, Jaiswal G. Evaluation of biological activities of Piper nigrum oil against Tribolium castaneum. Bull Insectology. 2007:60:57-61.

19. Awoyinka OA, Oyewole IO, Amos BMW, Onasoga OF. Comparative pesticidal activity of dichloromethane extracts of Piper nigrum against Sitophilus zeamais and Callosobruchus maculatus. Afr J Biotechnol. 2006;5:2446-9.

20. Chansang U, Zahiri NS, Bansiddhi J, Boonruad T, Thongsrirak P, Mingmuang J, et al. Mosquito larvicidal activity of aqueous extracts of long pepper (Piper retrofractum vahl) from Thailand. J Vector Ecol. 2005;30:195-200.

21. Junhirun P, Pluempanupat W, Yooboon T, Ruttanaphan T, Koul O, Bullangpoti $\mathrm{V}$. The study of isolated alkane compounds and crude extracts from Sphagneticola trilobata (Asterales: Asteraceae) as a candidate botanical insecticide for lepidopteran larvae. J Econ Entomol. 2018;111:1-7.

22. Akhtar Y, Isman MB. Comparative growth inhibitory and antifeedant effets of plant extracts and pure allelochemicals on four phytophagous insect species. J Appl Entomol. 2003;128:32-8.

23. Isman MB, Koul O, Luczynski A, Kaminski J. Insecticidal and antifeedant bioactivities of neem oils and their relationship to azadirachtin content. J Agric Food Chem. 1990;38:1406-11.

24. Feyereisen R. Comprehensive Molecular Insect Science. Compr Mol Insect Sci. 2005:4:1-77.

25. Bullangpoti V, Wajnberg E, Audant P, Feyereisen R. Antifeedant activity of Jatropha gossypifolia and Melia azedarach senescent leaf extracts on Spodoptera frugiperda (Lepidoptera: Noctuidae) and their potential use as synergists. Pest Manag Sci. 2012;68:1255-64.

26. Oppenoorth FJ, van der Pas LJT, Houx NWH. Glutathione S-transferase and hydrolytic activity in a tetrachlorvinphos-resistant strain of housefly and their influence on resistance. Pestic Biochem Physiol. Academic Press. 1979; 11:176-88.

27. Farzaei MH, Abbasabadi Z, Ardekani MRS, Rahimi R, Farzaei F. Parsley: a review of ethnopharmacology, phytochemistry and biological activities. J Tradit Chin Med. 2013:33:815-26.

28. Niroumand CM, Farzaei MH, Karimpour Razkenari E, Amin G, Khanavi M, Akbarzadeh T, et al. An evidence-based review on medicinal plants used as insecticide and insect repellent in traditional Iranian medicine. Iran Red Crescent Med J. 2016:18:1-8.

29. Farnsworth NR, Bunyapraphatsara N. Thai medicinal plants. Recommended for primary health care system. Bangkok: Prachachon; 1992.

30. Shukla R, Kumar A, Prasad CS, Srivastava B, Dubey NK. Efficacy of Acorus calamus $\mathrm{L}$. leaves and rhizome on mortality and reproduction of Callosobruchus chinensis L. (Coleoptera: Bruchidae). Appl Entomol Zool. 2009; 44:241-7

31. Wiwattanawanichakun P, Ratwatthananon A, Poonsri W, Yooboon T, Pluempanupat $\mathrm{W}$, Piyasaengthong $\mathrm{N}$, et al. The possibility of using isolated alkaloid compounds and crude extracts of Piper retrofractum (Piperaceae) as larvicidal control agents for Culex quinquefasciatus (Diptera: Culicidae) larvae. J Med Entomol. 2018:55:1231-6.

32. Shah P, Ghang M, Deshmukh P, Kulkarni Y, Joshi S, Vyas B, et al. Toxicity study of ethanolic extract of Acorus calamus rhizome. Int J Green Pharm. 2012;6:29-35.

33. Muthuraman A, Singh N. Acute and sub-acute oral toxicity profile of Acorus calamus (Sweet flag) in rodents. Asian Pac J Trop Biomed. 2012;2:S1017-23.

34. Prijono D, Sudiar JI, Irmayetri. Insecticidal activity of Indonesian plant extracts against the cabbage head caterpillar, Crocidolomia pavonana (F.) (Lepidoptera: Pyralidae). J Int Soc Southeast Asian Agric Sci. 2006;12:25-34

35. Dadang D, EvaDwi F, Djoko P. Effectiveness of two botanical insecticide formulations to two major cabbage insect pests on field application. J Issaas. 2009:15:42-51.

36. Kumar S, Warikoo R, Wahab N. Larvicidal potential of ethanolic extracts of dried fruits of three species of peppercorns against different instars of an Indian strain of dengue fever mosquito, Aedes aegypti L. (Diptera: Culicidae). Parasitol Res. 2010;107:901-7.

37. Fan LS, Rita M, Dzolkhifli O, Mawardi R. Insecticidal properties of Piper nigrum fruit extracts and essential oils against Spodoptera litura. Int J Agric Biol. 2011:13.517-22

38. Vinay S, Vahl P, Vahl PR, Renuka K, Palak V, Harisha CR, et al. Pharmacognostical and Phytochemical Study of Piper Longum. and Piper retrofractum Vahl. J Pharm Sci Innov. 2012;1:62-6.

39. Ahmad N, Fazal H, Abbasi BH, Farooq S, Ali M, Khan MA. Biological role of Piper nigrum L. (Black pepper): A review. Asian Pac J Trop Biomed. 2012:2:S1945-53.

40. Jiyavorranant T, Chanbang Y, Supyen D, Sonthichai S, Jatisatienr A. The effects of Acorus calamus Linn. and Stemona Tuberose Lour. extracts on the insect pest, Plutella xylostella (Linnaeus). Int Soc Hortic Sci. 2003;597:223-9. 
41. Phongpaichit S, Pujenjob N, Rukachaisirikul V, Ongsakul M. Antimicrobial activities of the crude methanol extract of Acorus calamus Linn. J Sci Technol. 2005;27:517-23.

42. Schmidt GH, Streloke M. Effect of Acorus calamus (L.) (araceae) oil and its main compound beta- asarone on Prostephanus truncatus (horn.) (coleoptera, bostrichidae). J Stored Prod Res. 1994;30:227-35.

43. Melani D, Himawan T, Afandhi A. Bioactivity of sweet flag (Acorus calamus Linnaeus) essential oils against Spodoptera litura Fabricius (Lepidoptera: Noctuidae). J Trop Life Sci. 2016:6:86-90.

44. Ganjewala D, Srivastava AK. An update on chemical composition and bioactivities of Acorus species. Asian J Plant Sci. 2011;10:182-9.

45. Liu XC, Zhou LG, Liu ZL, Du SS. Identification of insecticidal constituents of the essential oil of Acorus calamus rhizomes against Liposcelis bostrychophila badonnel. Molecules. 2013;18:5684-96.

46. Dadang E, Yunia N, Ohsawa K. Insecticidal activity of extract mixtures of four plant species against Crocidolomia pavanana (F.) (Lepidoptera pyralidae) larvae. J ISSAAS. 2007;13:9-17.

47. Li X, Schuler MA, Berenbaum MR. Molecular mechanisms of metabolicresistance to synthetic and natural xenobiotics. Annu Rev Entomol. 2007:52:231-53

48. Simon JY, Hsu EL. Induction of detoxification enzymes in phytophagous insects: role of insecticide synergists, larval age, and species. Arch Insect Biochem Physiol. 1993;24:21-32
49. Kaur A, Sohal SK, Arora S, Kaur H, Pal A. Effect of plant extracts on biochemistry of Bactrocera cucurbitae (Coquillett). J Entomol Zool Stud. 2014;2:86-92.

50. Bouayad N, Rharrabe K, Ghailani NN, Jbilou R, Castañera P, Ortego F. Insecticidal effects of Moroccan plant extracts on development, energy reserves and enzymatic activities of Plodia interpunctella. Spanish J Agric Res. 2013:11:189-98.

51. Zhou BG, Wang S, Dou TT, Liu S, Li MY, Hua RM, et al. Aphicidal activity of Illicium verum fruit extracts and their effects on the acetylcholinesterase and glutathione s-transferases activities in Myzus persicae (Hemiptera: Aphididae). J Insect Sci. 2016;16:1-7.

52. Hemming JDC, Lindroth RL. Effects of phenolic glycosides and protein on gypsy moth (Lepidoptera: Lymantriidae) and forest tent caterpillar (Lepidoptera: Lasiocampidae) performance and detoxication activities. Environ Entomol. 2000;29:1108-15.

53. Feng $R$, Chen $W$, Isman MB. Synergism of malathion and inhibition of midgut esterase activities by an extract from Melia toosendan (Meliaceae). Pestic Biochem Physiol. 1995;53:34-41.

\section{Submit your manuscript to a SpringerOpen ${ }^{\circ}$ journal and benefit from:}

- Convenient online submission

- Rigorous peer review

- Open access: articles freely available online

- High visibility within the field

- Retaining the copyright to your article

Submit your next manuscript at $\boldsymbol{\nabla}$ springeropen.com 